The Death Penalty 



\section{The Death Penalty}

\section{A N A M ERICAN HISTORY}

\section{STUART BANNER}

Cambridge, Massachusetts, and London, England 
Copyright (C) 2002 by the President and Fellows of Harvard College

All rights reserved

Printed in the United States of America

First Harvard University Press paperback edition, 2003

Third printing, 2003

\section{Library of Congress Cataloging-in-Publication Data}

Banner, Stuart, $1963-$

The death penalty : an American history / Stuart Banner.

p. $\mathrm{cm}$.

Includes bibliographical references and index.

ISBN o-674-00751-4 (cloth) ISBN o-674-01083-3 (pbk.)

1. Capital punishment-United States-History. 2. Capital punishment-Moral and ethical aspects - United States. 3. United States-Social conditions. I. Title.

$$
\begin{gathered}
\text { HV8699. } U_{5} \mathrm{~B}_{3} 6_{7} 2002 \\
364.66^{\prime} 0973-\mathrm{dc} 21 \\
2001047047
\end{gathered}
$$


For Tamara: donec gratus sum tibi, Persarum vivo rege laetior 
